Discussion Paper No. 787

\title{
RESALE PRICE MAINTENANCE BY JAPANESE NEWSPAPERS
}

David Flath

August 2010

The Institute of Social and Economic Research Osaka University

6-1 Mihogaoka, Ibaraki, Osaka 567-0047, Japan 
August 30, 2010

\title{
Resale Price Maintenance by Japanese Newspapers
}

\author{
David Flath* \\ Institute of Social and Economic Research, Osaka University \\ abstract
}

In Japan, newspapers enjoy a special exemption from antimonopoly prohibitions against resale price maintenance (suppliers' stipulations that bar downstream firms from price discounting), but are each required to set uniform prices throughout Japan. In fact, the newspapers have rarely changed their subscription prices in recent years, and the three leading national dailies, together accounting for about half the total industry circulation, and thirteen other papers accounting for another one eighth of industry circulation, all have set exactly the same price (3,925 yen per month). The remaining local papers all set lower prices. The authorized resale price maintenance, and prohibition against prices that vary geographically, have allowed collusive price increases that I here estimate to be around 500 yen per month, entailing economic waste of about 300-billion yen (\$3-billion) per year but adding only around 16-billion yen per year to newspaper profit. The increased profit margin on subscriptions is much offset by reduced sale of ads.

JEL codes: D4,L4

Keywords: resale price maintenance, two-sided markets, newspapers, advertising

\author{
*Institute of Social and Economic Research \\ Osaka University \\ 6-1 Mihogaoka, Ibaraki \\ Osaka 567-0047 \\ JAPAN
}

Tel: 81-(0)6-6879-8569

E-mail: flath@iser.osaka-u.ac.jp

This research is supported by Japan Society for the Promotion of Science, Grant-in-Aid for Scientific Research (C), grant no. 22530227. 


\section{Resale Price Maintenance by Japanese Newspapers}

\section{Introduction.}

In Japan, newspapers enjoy a special exemption from antimonopoly prohibitions against resale price maintenance (suppliers' stipulations that bar downstream firms from price discounting), but are each required to set uniform prices throughout Japan. The national dailies, and thirteen of the leading regional and local dailies, have exploited this antitrust exemption to maintain collusive subscription fees. This has benefitted the other local dailies and may have promoted improvements in content, but has wastefully diverted resources away from the newspaper business and towards other less valued activities. I estimate this waste to be in the neighborhood of 300-billion yen per year (about \$3-billion per year). I further calculate that increasing the subscription price has only enriched the colluding newspapers by around 16-billion yen per year. The enlarged profit margin on subscriptions that comes from raising the price is largely dissipated in reduced sales of advertising. This is an unusual cartel indeed. The waste it imposes is nearly twenty times greater than the added profit it collects.

Collusive price-setting by Japan's leading newspapers imposes economic waste vastly out of proportion to the added profit it confers for two reasons. First, the newspapers are horizontally differentiated. They would each exhibit a degree of market power even without colluding. Ihere estimate the elasticity of demand facing the typical Japanese newspaper as 2.3. The papers that seem to have colluded in setting a common price have, in my estimates, set that price about 15 percent higher than they would have done if acting independently. If in setting the common price they have maximized profit, then I infer that the elasticity of demand they face with respect to adjustments in that price must be around 2.0, lower than the 2.3 elasticity with respect to adjustments only in own price because of the positive cross elasticity of demand among the colluding papers. The cross elasticities are small. The newspapers gain something by colluding but not much.

The second reason why the collusive profit is small relative to the economic waste is that the newspapers sell advertising as well as subscriptions. I estimate the elasticity of demand for advertising in any Japanese newspaper as 3.5. Because selling advertising is profitable and the demand for advertising is proportionate to newspaper circulation, the newspapers tend to set lower subscription prices than they would if not selling ads. But this means that the loss in 
consumer surplus from rasing the subscription price is relatively great because the price increase is applied to a large circulation and because the induced constriction of circulation reduces the consumer surplus of advertisers as well as subscribers. Before describing the analysis and estimates on which these inferences are based, I shall first describe some relevant features of the Japanese newspaper industry and its pricing practices.

\section{The Japanese Newspaper Industry.}

Japan has five national news dailies (Mainichi, Asahi, Yomiuri, Nikkei and Sankei), a couple of large circulation regional papers (Chunichi Shimbun, Hokkaido Shimbun), and another 40 or 50 newspapers that mainly serve a single prefecture or city. The Nikkei, often compared with the Wall Street Journal, features business and financial news. Sankei Shimbun is similar to Nikkei. The other three national dailies, Yomiuri, Mainichi, and Asahi, together account for about half the total circulation of all newspapers. The total circulation of news dailies (not including sports dailies, tabloids, or political newspapers) in Japan is about 85 percent of the number of households and more than 95 percent of sales are by monthly subscription rather than single-issue. Figure 1 shows the market shares of the national papers, regional papers and local papers in each prefecture, in 2007. It is evident that the local papers gain larger shares in the less populous prefectures.

The newspaper publishers distribute through independent newsdealers. The typical arrangement entails an exclusive geographic territory assigned by the newspaper company, daily purchase of a number of copies, the number being set by the newspaper company, and resale at a price stipulated by the newspaper-exclusive territory, stipulated resale price and a sales quota. That the newspapers enforce sales quotas, which would violate antimonopoly proscriptions, is widely denied by the newspaper companies but is evidently a fact. The newspapers that are shipped and billed to the distributors, and unwanted by them, are referred to as oshigami-literally "push papers". Documentation of this practice can be found in the Wikipedia entry for "shinbun hanbai ten" (newspaper sellers in Japan). It is also usual and expected that the distributors will be paid by advertisers to include inserts in the papers they distribute. Most newsdealers distribute only one newspaper. The newspaper companies also contract with independent operators besides the newsdealers to solicit new subscriptions.

The Japanese newspapers, and other publishers, enjoy a special exemption from antimonopoly 
prohibitions against resale price maintenance (Antimonopoly, Section 23-2 (4)). The exemption dates from the 1953 amendments to the 1947 Antimonopoly Law. Newspaper publishers are also bound by a special directive of the Japan Fair Trade Commission enjoining against charging differing prices according to the area or person buying (most recently "Specific Unfair Trade Practices in the Newspaper Business”, Fair Trade Commission Notification, no. 9, July 21, 1999, amending the similar earlier notification no. 14, 1964). The directive also disallows discount pricing by newspaper distributors, and disallows the newspaper publishers from imposing minimum quantities (sales quotas) on distributors, though apparently as already stated the publishers do this anyway. Under the special directive, each newspaper is free to set its own price but must then charge that same price wherever the newspaper is sold. Different editions of the newspaper may command differing prices. At least since 1945 and probably before that, the three leading national dailies Yomiuri, Asahi and Mainichi, have all set the same subscription price as one another and changed that price at roughly the same time as one another. Price changes are infrequent. The last price change was in 2003, seven years ago. Since then a monthly subscription to any of them is 3,925 yen (around \$40). The Japan Newspaper Association has publicly supported the continuation of the special antitrust exemption allowing newspapers to maintain retail prices and indeed forestalled the adoption of a proposal in 2001 to repeal it.

Why resale price maintenance? A quick -and I think wrong- answer is that the retail price stipulation is actually a maximum retail price and is to prevent the independent distributors from exploiting the local monopolies that their exclusive territories confer. By raising the price to increase its own profit a distributor would actually diminish the total profit in the supply chain, the successive monopoly problem. Those who are familiar with US antitrust law will recall the Albrecht case ${ }^{1}$ in which Herald Publishing Company, publisher of the St. Louis Globe Democrat, was found by the U. S. Supreme Court to have violated prohibitions against resale price maintenance in an apparent attempt to deter exactly this sort of overpricing. The resale price maintenance of Japanese newspapers is different because the sales quotas that the newspapers impose on the distributors deter the distributors from raising prices. The sales quotas are set at levels that not only deter overpricing but that also encourage solicitation of new subscriptions. Because of this, the stipulated retail prices are binding downward; they are price floors, not price

${ }^{1}$ Albrecht v., Herald Co., 390 U.S. 145 (1968). 
ceilings. A simple explanation is that the resale price maintenance is part of a cartel scheme among the newspaper companies.

Examples of resale price maintenance as a producer cartel scheme have been noted empirically and explored theoretically. We have the Telser (1960) discussion of the light bulb case. In the early twentieth century, duopolists Westinghouse and GE sold light bulbs through exclusive independent retail outlets and both stipulated the same minimum resale prices. In Telser's explanation, retail price discounting could be more easily detected and deterred than could wholesale price discounting, and exclusive dealing prevented retailers' profiting from any secret wholesale price discounts that were not passed on as retail price discounts. In Flath (1989) I suggested that a producer cartel scheme was the likely motive for resale price maintenance by the three producers of infant powdered milk in Japan, as documented in a series of antimonopoly cases, from the 1960s and 1970s. Jullien and Rey (2007) develop an algebraic model in which resale price maintenance facilitates collusion among producers because it makes deviations from the collusive scheme easier for the colluders to detect and credibly deter, as explained by Telser. This seems to me to be the essence of the Japanese newspaper cartel too.

Another collusive practice of the Japanese newspaper industry is the newspaper holiday. On one particular Monday each month, the newspapers all refrain from issuing a morning and evening edition. The Japan Newspaper association defends this practice as needed to give the newspaper distributors vacation days. This is absurd. By rotating work shifts or deploying substitute workers newsdealers could permit vacations. The newspaper holidays amount to a collusive restriction of industry output, for both distributors and publishers. The fact that the newspaper holidays of the different papers are on the same days is evidence of collusion among the newspaper companies. A rare instance of deviation is also revealing. In February 2002, the Sankei Shimbun refrained from the practice of newspaper holiday. The other papers publicly criticized Sankei but also themselves refrained from holidays. Three months later the practice was reinstated, again with Sankei participating. That deviation by Sankei triggered deviations by the others strongly suggests that the newspaper holidays have the character of a prisoners' dilemma, as is generally true of cartel schemes.

My aim is to assess the actual increase in prices that can be attributed to collusive behavior by the leading Japanese newspapers, and determine also the likely effects of those price increases on profits, consumer surplus and newspaper content. I begin by laying out a simple algebraic 
framework for interpreting data on newspaper prices, circulation, advertising and content. Much of this will be familiar to students of newspaper economics. Similar models have been sketched in Rosse (1970), Blair and Romano (1993), Van Cayseele and Vanormelingen (2009), and elsewhere. Here I adapt the framework for analysis of the Japanese newspaper industry.

\section{Basic Framework.}

Let us suppose that the demand for ads "a" depends on the price to place an ad per subscriber " $\mathrm{p}_{\mathrm{a}} / \mathrm{s}$ " and that the readers regard the ads indifferently. Here an ad is defined as a printed item supplied to all subscribers, the same as the subscription content $\mathrm{k}$. The only difference is that the ad is paid for by the advertiser but the other content is paid for by the subscribers. To keep matters simple, posit a constant elasticity demand system facing the newspaper:

$$
\begin{aligned}
& \mathrm{s}=A \mathrm{p}_{\mathrm{s}}^{-\xi \mathrm{s}} \mathrm{k}^{\theta} \\
& \mathrm{a}=\mathrm{B}\left(\mathrm{p}_{\mathrm{a}} / \mathrm{s}\right)^{-\xi \mathrm{a}},
\end{aligned}
$$

where $\xi_{\mathrm{s}}>1, \xi_{\mathrm{a}}>1$, and $0<\theta<1$. Specifying the demand for advertising in this way does rule out some interesting cases. For example, it disallows cases in which demand for advertising depends not only on circulation but also on newspaper content that targets specific types of readers. These cases are usefully explored by Chandra and Collard-Wexler (2008). The data on Japanese newspapers that I analyze here unfortunately does not allow investigation of reader targeting and its effects.

Let the cost of newspaper production depend on number of ads and circulation and on amount of content. These costs include first-copy costs $\mathrm{f}_{\mathrm{a}} \mathrm{a}+\mathrm{f}_{\mathrm{k}} \mathrm{k}$, and costs that depend on number of copies $\mathrm{c}_{0} \mathrm{~s}+\overline{\mathrm{c}} \mathrm{as}+\overline{\mathrm{cks}}$ :

$$
\text { Cost }=\mathrm{f}_{\mathrm{a}} \mathrm{a}+\mathrm{c}_{0} \mathrm{~s}+\overline{\mathrm{c}} \mathrm{as}+\mathrm{f}_{\mathrm{k}} \mathrm{k}+\overline{\mathrm{cks}} .
$$

Here, $c_{0}$ is the unit cost of distribution (net of advertisers' payments to distributors for including inserts), $\overline{\mathrm{c}}$ is the cost per page of actually printing the newspaper (where $\mathrm{k}$ are the number of pages of content and " $a$ " the pages of ads), $\mathrm{f}_{\mathrm{k}}$ is the first-copy cost of producing a page of content and $f_{a}$ is the first-copy cost of producing a page of advertising. Notice that because of the term cas in the cost function, the costs are not separable into cost of subscription and cost of advertising. This makes it problematic to speak separately of the profits from subscriptions and from advertising.

The incremental costs $\mathrm{c}_{\mathrm{s}}, \mathrm{c}_{\mathrm{a}}$, and $\mathrm{c}_{\mathrm{k}}$ of supplying subscriptions, ads and content are the 
following:

$$
\begin{aligned}
& \mathrm{c}_{\mathrm{s}} \equiv \partial \operatorname{Cost} / \partial \mathrm{s}=\mathrm{c}_{0}+\overline{\mathrm{c}} \mathrm{a}+\overline{\mathrm{c}} \mathrm{k} \\
& \mathrm{c}_{\mathrm{a}} \equiv \partial \operatorname{Cos} \mathrm{t} / \partial \mathrm{a}=\mathrm{f}_{\mathrm{a}}+\overline{\mathrm{c}} \mathrm{s} \\
& \mathrm{c}_{\mathrm{k}} \equiv \partial \operatorname{Cost} / \partial \mathrm{k}=\mathrm{f}_{\mathrm{k}}+\overline{\mathrm{c}} \mathrm{s}
\end{aligned}
$$

The newspaper chooses content, price of ads, and price of subscriptions to maximize total profit:

$$
\begin{aligned}
& \max \pi\left(p_{s}, p_{a}\right)=p_{s} s+p_{a} a-f_{a} a-\bar{c} a s-f_{k} k-\overline{c k s}-c_{0} s \\
& p_{s}, p_{a}, k
\end{aligned}
$$

The necessary conditions for maximum profit reduce to the following pricing rules ${ }^{2}$ :

$$
\begin{aligned}
& \left(\mathrm{p}_{\mathrm{a}}-\mathrm{c}_{\mathrm{a}}\right) / \mathrm{p}_{\mathrm{a}}=1 / \xi_{\mathrm{a}} \\
& \left(\mathrm{p}_{\mathrm{s}}-\mathrm{c}_{\mathrm{s}}\right) / \mathrm{p}_{\mathrm{s}}=1 / \xi_{\mathrm{s}}-\mathrm{p}_{\mathrm{a}} \mathrm{a} / \mathrm{p}_{\mathrm{s}} \mathrm{s} .
\end{aligned}
$$

Profit-maximizing also requires that content $\mathrm{k}$, the number of pages not including ads, fulfills the condition:

$$
\mathrm{f}_{\mathrm{k}} \mathrm{k} / \mathrm{p}_{\mathrm{s}} \mathrm{s}=\theta / \xi_{\mathrm{s}}
$$

This expression resembles the Dorfman-Steiner condition describing optimal advertising expenditure. This is because, analytically, the model here is the same as the Dorfman-Steiner advertising model: Demand for subscriptions has constant elasticity $(0<\theta<1)$ with respect to content, just as in the Dorfman-Steiner model demand for the product has constant elasticity with respect to quantity of ads.

Rearranging in a useful way, the pricing and content rules are:

$$
\begin{aligned}
& \mathrm{p}_{\mathrm{a}}=\left(\mathrm{f}_{\mathrm{a}}+\overline{\mathrm{c}} \mathrm{s}\right)\left(1-1 / \xi_{\mathrm{a}}\right)^{-1} \\
& \mathrm{p}_{\mathrm{s}}=\left(\mathrm{c}_{0}+\overline{\mathrm{c}} \mathrm{k}+\overline{\mathrm{c}} \mathrm{a}-\mathrm{p}_{\mathrm{a}} \mathrm{a} / \mathrm{s}\right)\left(1-1 / \xi_{\mathrm{s}}\right)^{-1} . \\
& \mathrm{k}=\theta \mathrm{p}_{\mathrm{s}} \mathrm{s} / \xi_{\mathrm{s}} \mathrm{f}_{\mathrm{k}} .
\end{aligned}
$$

The subscription price $\mathrm{p}_{\mathrm{s}}$ is set as though the newspaper were receiving a subsidy per subscriber

\footnotetext{
${ }^{2}$ The price-cost margin for subscriptions exemplifies the behavior of a multi-product monopolist supplying two goods that are complements in demand. In general, where the demands are as follows

$$
\begin{aligned}
& \mathrm{Q}_{1}=A \mathrm{p}_{1}{ }^{\xi 1} \mathrm{p}_{2^{-}}{ }^{\xi 12} \\
& \mathrm{Q}_{2}=\mathrm{B} \mathrm{p} \mathrm{p}^{-{ }^{-\xi 2}} \mathrm{p}_{1}{ }^{\xi 21},
\end{aligned}
$$

and marginal costs are $c_{1}$ and $c_{2}$, the profit-maximizing pricing rules are:$$
\left(\mathrm{p}_{1}-\mathrm{c}_{1}\right) / \mathrm{p}_{1}=1 / \xi_{1}+\left(\left(\mathrm{p}_{2}-\mathrm{c}_{2}\right) / \mathrm{p}_{2}\right)\left(\xi_{21} / \xi_{1}\right)\left(\mathrm{p}_{2} \mathrm{Q}_{2} / \mathrm{p}_{1} \mathrm{Q}_{1}\right)
$$$$
\left(\mathrm{p}_{2}-\mathrm{c}_{2}\right) / \mathrm{p}_{2}=1 / \xi_{2}+\left(\left(\mathrm{p}_{1}-\mathrm{c}_{1}\right) / \mathrm{p}_{1}\right)\left(\xi_{12} / \xi_{2}\right)\left(\mathrm{p}_{1} \mathrm{Q}_{1} / \mathrm{p}_{2} \mathrm{Q}_{2}\right)
$$

See for example Tirole (1988, pp.69-71). But here the cross-elasticities of demand are:

$\xi_{12}=\partial \ln \mathrm{a} / \partial \ln \mathrm{p}_{\mathrm{s}}=-\xi_{\mathrm{a}} \xi_{\mathrm{s}}\left(=\xi_{1} \xi_{2}\right)$, and

$\xi_{21}=\partial \ln \mathrm{s} / \partial \ln \mathrm{p}_{\mathrm{a}}=0$.
} 
equal to the marginal profit that arises indirectly from advertising with each copy sold (for given price of advertising $\left.p_{a}\right)$ :

$$
\begin{aligned}
\left(\partial\left(p_{a} a-f_{a} a-\bar{c} a s\right) / \partial a\right)(\partial a / \partial s)+\left(\partial\left(p_{a} a-f_{a} a-\bar{c} a s\right) / \partial s\right. & =\left(p_{a}-f_{a}-\overline{c s}\right)(\partial a / \partial s)-\overline{c a} \\
& =\left(p_{a}-f_{a}-\bar{c} s\right) p_{a} \xi_{a} / s-\overline{c a} \\
& =p_{a} a / s-\bar{c} a
\end{aligned}
$$

This marginal profit equals the marginal revenue that arises indirectly from advertising $\left(=p_{a} a / s\right)$, minus the added-cost-per-copy attributable to advertising $(=\bar{c} a)$.

The basic framework can be summarized in two sets of equations:

(1) Givens:

Demand for subscriptions: $\quad \mathrm{s}=\mathrm{A} \mathrm{p}_{\mathrm{s}}^{-\xi^{-\xi s}} \mathrm{k}^{\theta}$

Demand for ads: $\quad \mathrm{a}=\mathrm{B}\left(\mathrm{p}_{\mathrm{a}} / \mathrm{s}\right)^{-\xi \mathrm{ga}}$,

Cost function: $\quad \operatorname{Cost}=\mathrm{f}_{\mathrm{a}} \mathrm{a}+\mathrm{c}_{0} \mathrm{~s}+\overline{\mathrm{c}} \mathrm{as}+\mathrm{f}_{\mathrm{s}} \mathrm{k}+\overline{\mathrm{c}} \mathrm{ks}$.

(2) Implied by profit-maximization (pricing and content rules):

Price of ads:

$\mathrm{p}_{\mathrm{a}}=\left(\mathrm{f}_{\mathrm{a}}+\overline{\mathrm{c}} \mathrm{s}\right)\left(1-1 / \xi_{\mathrm{a}}\right)^{-1}$

Price of subscriptions:

$\mathrm{p}_{\mathrm{s}}=\left(\mathrm{c}_{0}+\overline{\mathrm{c}} \mathrm{k}+\overline{\mathrm{c}} \mathrm{a}-\mathrm{p}_{\mathrm{a}} \mathrm{a} / \mathrm{s}\right)\left(1-1 / \xi_{\mathrm{s}}\right)^{-1}$.

Pages of content:

$\mathrm{k}=\theta \mathrm{p}_{\mathrm{s}} \mathrm{s} / \xi_{\mathrm{s}} \mathrm{f}_{\mathrm{k}}$

The pricing and content rules do not depend directly on the parameters $\mathrm{A}$ and $\mathrm{B}$ that scale the demands for ads and for subscriptions. With given values for the other parameters $\left(f_{a}, f_{s}, f_{k}, c_{0}\right.$, $\bar{c}, \theta, \xi_{s}$, and $\left.\xi_{\mathrm{a}}\right)$, the prices and content $\left(\mathrm{p}_{\mathrm{a}}, \mathrm{p}_{\mathrm{s}}\right.$, and $\left.\mathrm{k}\right)$ are determined by the number of subscriptions $\mathrm{s}$ and demand for ads a. My basic estimating strategy is to treat $\mathrm{s}$ and a as exogenous. An admittedly better method would be to instrument s and a with correlates of the demand shifters A and B, but data that would enable me to do this has so far eluded me. I boldly plunge ahead with the data I have.

\section{Estimates and Implications.}

There are two different ways of estimating the parameters. One is to estimate the demand and cost functions directly. The other is to estimate the functions that describe the profit-maximizing rules for choosing prices and content. The literature on newspaper economics includes examples of both approaches. Van Cayseele and Vanormelingen (2009) estimate a pair of equations 
describing the demand for ads and demand for subscriptions in Belgian newspapers. The demand for subscriptions is specified as nested logit, in which readers first choose between subscription to the local paper versus a national one, and then choose within the one category or the other. Demand for subscriptions depends on the characteristics of newspapers and of readers, and on the prices. Van Cayseele and Vanormelingen find that the elasticity of demand for subscriptions $\xi_{\mathrm{s}}$ ranges from 1.25 to 3.05 . They estimate a demand for advertising directly and find a price elasticity of $\xi_{\mathrm{a}} \approx 1.5$. Argentesi and Filistrucchi (2007) estimate a nested logit specification for reader demand and simple logit specification for advertising demand for Italys' four national newspapers. In their preferred specification the newspapers set ad rates noncooperatively but collude in setting cover prices.

Rosse (1970) estimates a set of equations approximately like the three pricing and content rules implied by profit-maximization, using data for local newspapers across the US. Rosse allows for curvature of the cost function (which the simple model here does not exhibit), and also allows demand for subscriptions to depend directly on amount of ads. He finds a price elasticity of demand for subscriptions $\xi_{\mathrm{s}} \approx 1.4$, taking into account the effect of change in subscription price on amount of ads, as interpreted by Blair and Romano (1993). He also finds that price elasticity of demand for advertising is $\xi_{\mathrm{a}} \approx 1.6$. Rosse was the first to notice that variation in demand across cities could be exploited as a kind of natural experiment in measuring the effect of shifting demand on the costs and pricing of local newspaper monopolists. As far as I am aware this same principal has not yet been exploited in the study of Japan's local newspapers.

\subsection{Price of advertising.}

Within the basic framework, much of the variation in price of advertising across local newspapers can be related to variation in number of subscribers s. The price of ads (not per subscriber) varies linearly with number of subscribers. Newspapers with smaller circulation, all else the same, have lower ad prices:

$$
\mathrm{dp}_{\mathrm{a}} / \mathrm{ds}=\overline{\mathrm{c}}\left(1-1 / \xi_{\mathrm{a}}\right)^{-1}>0,
$$

but higher ad prices per subscriber:

$$
\mathrm{d}\left(\mathrm{p}_{\mathrm{a}} / \mathrm{s}\right) / \mathrm{ds}=-\mathrm{f}_{\mathrm{a}}\left(1-1 / \xi_{\mathrm{a}}\right)^{-1} \mathrm{~s}^{-2}<0 .
$$

It is possible that elasticity of demand for advertising varies from one newspaper to another. But much of the actual variation in ad pricing across Japan's local newspapers is linearly related to 
number of subscribers, as implied by the model just described.

Table 1 reports OLS regressions in which newspaper ad pricing is a linear function of circulation. There are four different prices, so four separate regressions. The dependent variable in the left-most regression of the table is the price for a legal notice posted in the society page per $1 \mathrm{~cm}$ horizontal column (dan in Japanese). This is the basic plain-vanilla ad rate that is the anchor for each newspaper's menu of ad prices. The dependent variables in the other three Table 1 regressions are contract prices per horizontal column for black-and-white business display ads. These vary depending on whether the contract is for one, five or fifteen horizontal columns, within a six-month period. A page is divided into fifteen horizontal columns, so these are prices for one-fifteenth page, one-third page or one page, cumulatively within the contract period (The price is the same for a full page ad as for fifteen one-column ads). The rate for ads smaller than one horizontal column is the same as for a legal notice and is priced per horizontal column per centimeter width. A (Yomiuri shimbun) page is $37.9 \mathrm{~cm}$ wide. A (perhaps typical) small ad might amount to one half column (in other words $1 / 30$ th of a page), and so its price would be $18.95 \mathrm{x}$ the price per column centimeter for a legal notice. The regressions use 2003 circulation because 2003 was the year in which the prices were last changed; they have remained the same in the seven years since then. The unit of observation is the particular edition of each paper. Some of the observations are for ads placed in more than one regional edition of a national newspaper. For these I aggregated the circulation over the regional editions covered. With those observations excluded, Chow tests favored the pooling of national and local papers. Chow tests favored pooling of morning and evening editions even with those observations included. The estimates reported in Table 1 are for the pooled sample. The R-squared is 0.75 for legal notice and 0.85 to 0.90 for the business display ads. It seems that the basic framework adequately describes the newspaper advertising cost function and the ad pricing behavior of newspapers. That is the newspapers each face a similar elasticity of demand for advertising and have similar first-copy costs of supplying advertising. The newspapers with greater circulation have correspondingly lower incremental costs and so set lower prices. Picard (1998) notes an approximately similar pattern in the advertising rates of U.S. newspapers.

\subsection{Content.}

For given parameters $\left(\theta, \xi_{s}\right.$, and $\left.f_{k}\right)$, content $\mathrm{k}^{*}$ is proportionate to revenue from subscriptions 
$\mathrm{p}_{\mathrm{s}} \mathrm{s}$. That is: $\mathrm{k}^{*}=\theta \mathrm{p}_{\mathrm{s}} \mathrm{s} / \xi_{\mathrm{s}} \mathrm{f}_{\mathrm{k}}$. An implication of this basic framework is that newspapers that face a decline in demand for subscriptions will reduce content.

Subscription price per page of content $\mathrm{p}_{\mathrm{s}} / \mathrm{k}^{*}$ is proportionate to $1 / \mathrm{s}$

$$
\mathrm{p}_{\mathrm{s}} / \mathrm{k}^{*}=\xi_{\mathrm{s}} \mathrm{f}_{\mathrm{k}} / \theta \mathrm{s} .
$$

Notice that $\partial \ln \left(\mathrm{p}_{\mathrm{s}} / \mathrm{k}^{*}\right) / \partial \mathrm{s}=-1$, but this is not the elasticity of demand. It is a reduced form relationship between $\mathrm{s}$ and $\mathrm{p}_{\mathrm{s}} / \mathrm{k}^{*}$ as other parameters shift. In fact, it is premised on constant elasticity of demand $\partial \mathrm{s} / \partial \ln \mathrm{p}_{\mathrm{s}} \equiv \xi_{\mathrm{s}}>1$. In the Argentesi and Filistrucchi (2007) estimates of reader demand facing Italy's four national newspapers the dependent variable is real price per issue, which is something like price per page of content. Most of the variation arises from which days happened to include weekly supplements. They report, at the sample mean, the elasticity of reader demand with respect to variation in real price of around 0.75 , not too different from one, as would be implied by the logic just related. I have not so far been able to estimate $\theta$. My conjecture is that it is rather small. Large circulation papers and small circulation papers both have about 15 to 20 pages of content per morning issue.

\subsection{Price of subscriptions.}

To analyze the effect of collusive price setting requires that we expand the basic framework to show how the demands for subscription to each newspaper depend on the prices of rival newspapers. For example write the demand for subscription to newspaper 1

$$
\mathrm{s}_{1}=\mathrm{A}_{1} \mathrm{p}_{\mathrm{s} 1}^{\xi s 1} \mathrm{k}^{\theta} \prod_{\mathrm{i} \neq 1} \mathrm{p}_{\mathrm{si}}^{\xi 1 \mathrm{\xi}}
$$

where $\xi_{1 \mathrm{i}}\left(=\partial \ln \mathrm{s}_{1} / \partial \ln \mathrm{p}_{\mathrm{i}}\right)>0$ is the cross-elasticity of demand for subscriptions among rivals. Here stipulate that $\xi_{\mathrm{s} 1}-\sum \xi_{1 \mathrm{i}}>1$. In other words, the rival newspapers are substitutes in demand $\left(\xi_{1 \mathrm{i}}>0\right)$, and if their prices are the same, demand responds elastically to adjustment in their common price. Under the Japan Fair trade Commission special directive each newspaper is obliged to set geographically uniform prices but need not set the same price as rival newspapers. Nikae (2010) usefully points out that the legally mandated geographic uniformity can itself lead to softer price competition. This is not part of my analysis. My focus here is on the collusive setting of a common price.

Now the national newspapers in Japan (Yomiuri, Asahi, and Mainichi) do in fact all set the same subscription price:

$$
\mathrm{p}_{\mathrm{s} 1}=\mathrm{p}_{\mathrm{s} 2}=\mathrm{p}_{\mathrm{s} 3}=\mathrm{p}_{\mathrm{s}^{*}}
$$


For these three, the demand each faces becomes

$$
\mathrm{s}_{\mathrm{i}}=\mathrm{A}_{\mathrm{i}} \mathrm{p}_{\mathrm{s}^{*}}{ }^{-\xi} \mathrm{s} 1+\xi 2 \mathrm{\xi}+\xi 3 \mathrm{i} \mathrm{k}^{\theta} \prod_{\mathrm{i} \neq 1,2,3} \mathrm{p}_{\mathrm{si}}{ }^{\xi 1 \mathrm{i}}, \mathrm{i}=1, \ldots, 3 \text {. }
$$

Among the three, each would want to set a higher common price $\mathrm{p}_{\mathrm{s}^{*}}$ than the price it would choose in the Bertrand equilibrium. But the one with lower incremental costs of subscriptions or greater ad revenue per subscriber would want a lower common price than the others. Perhaps the difference among the three in preferred common price is not so great, or perhaps they are able to reach a consensus. Whichever of these is true, the common price is higher than the Bertrand prices of each of them and this is the essence of resale price maintenance among the national newspapers in Japan. The subscription prices of the colluding firms under the resale price maintenance regime are higher than they otherwise would be. Their non-colluding rivals enjoy an increased demand as a result of the collusive price increase, but set the same Bertrand prices as they would in the absence of collusion. The two bloc newspapers Chunichi Shimbun and Hokkkaido Shimbun, and the other national paper Sankei Shimbun, all set the same 3,925 yen per month subscription price as the big three national papers. So do eleven of the local newspapers. That leaves seven local newspapers offering both morning and evening editions at lower subscription prices. The Shizuoka Shimbun is the largest circulation newspaper among the seven with a subscription price below that of the national dailies. Its subscription price is 2,900 yen and its circulation tops 700,000.

Some descriptive statistics on newspapers are in Table 2. These are reported separately for the various editions of the sixteen newspaper that are setting the same 3,925 yen per month price of subscription, and for the local papers that are setting lower subscription prices. These are the data I use to analyze subscription prices. The data sources are noted in Appendix 1.

My strategy is to estimate an equation explaining the subscription prices of the newspaper companies that set prices below the 3,925 yen per month set by Yomiuri, Asahi, and Mainichi, and then use that equation to predict out of sample the subscription prices of the others. Comparison of the predicted prices and the actual ones measures the effect of the resale price maintenance collusion. The estimating equation comes from substituting the price-of-ads equation, $\mathrm{p}_{\mathrm{a}} / \mathrm{s}=\left(\mathrm{f}_{\mathrm{a}} / \mathrm{s}+\overline{\mathrm{c}}\right)\left(1-1 / \xi_{\mathrm{a}}\right)^{-1}$, for $\mathrm{p}_{\mathrm{a}} / \mathrm{s}$ in the subscription-pricing equation. I report the estimate of the resulting equation in Table 3 and also directly below the equation itself here: 


$$
\mathrm{p}_{\mathrm{s}}=\mathrm{c}_{0}\left(1-1 / \xi_{\mathrm{s}}\right)^{-1}+\overline{\mathrm{c}}\left(1-1 / \xi_{\mathrm{s}}\right)^{-1}(\mathrm{k}+\mathrm{a})-\overline{\mathrm{c}}\left(1-1 / \xi_{\mathrm{a}}\right)^{-1}\left(1-1 / \xi_{\mathrm{s}}\right)^{-1} \mathrm{a}-\mathrm{f}_{\mathrm{a}}\left(1-1 / \xi_{\mathrm{a}}\right)^{-1}\left(1-1 / \xi_{\mathrm{s}}\right)^{-1} \mathrm{a} / \mathrm{s}
$$

\begin{tabular}{|c|c|c|c|c|c|}
\hline $\mathrm{p}_{\mathrm{s}}=$ & $\beta_{0}$ & $+\beta_{1}(\mathrm{k}+\mathrm{a})$ & $+\beta_{2}$ & $\mathrm{a}$ & $+\beta_{3}$ \\
\hline $\mathrm{p}_{\mathrm{s}}=$ & $\begin{array}{r}2,723 \\
(+434 \\
\text { if dual } \\
\text { edition) }\end{array}$ & $+0.5(\mathrm{k}+\mathrm{a})$ & -0.7 & $\mathrm{a}$ & - 103,929 \\
\hline $\begin{array}{l}\text { standard error: } \\
\text { t value: } \\
\text { one-sided } \mathrm{p} \text { : }\end{array}$ & & $\begin{array}{r}0.6 \\
0.88 \\
0.193\end{array}$ & $\begin{array}{r}1.1 \\
-0.6 \\
0.276\end{array}$ & & $\begin{array}{r}62,873 \\
-1.65 \\
0.054\end{array}$ \\
\hline R-square: & 0.436 & & & & \\
\hline
\end{tabular}

Although the standard errors are large, the signs are as expected and the orders of magnitude of the coefficients are sensible. From the estimate, the elasticity of demand for advertising is computed as $\xi_{\mathrm{a}}=\left(1+\beta_{1} / \beta_{2}\right)^{-1}=(1-0.5 / 0.7)^{-1}=3.5$. This seems about right, though higher than the corresponding estimate for Belgian newspapers $(=1.5)$ reported by Van Cayseele and Vanormelingen (2009).

For the price elasticity of demand for subscriptions we can use the slope coefficient from the advertising price regression to make an inference. From the Table 1 regressions it seems that the slope for business display ads is around $0.4=\partial \mathrm{p}_{\mathrm{a}} / \partial \mathrm{s}=\overline{\mathrm{c}}\left(1-1 / \xi_{\mathrm{a}}\right)^{-1}$, so for $\xi_{\mathrm{a}}=3.5$ we have $\overline{\mathrm{c}} \approx 0.4 / 1.4=0.29$ from which we infer $\xi_{\mathrm{s}}=\left(1-\overline{\mathrm{c}} / \beta_{1}\right)^{-1}=2.3$.

The equation estimate in the text box (the same as in Table 3 ) is used to predict subscription prices for the out-of-sample newspapers, that is for the national newspapers and the others that set the same 3,925 yen per month subscription price as Yomiuri, Asahi and Mainichi. These predictions, standard errors of prediction and prediction errors are reported in the last columns of Table 4. The prediction errors are positive and indicate that subscriptions to the national dailies and others are 500 yen or more per month higher than if their pricing behavior mimicked that of the other local papers. The average prediction errors are Yomiuri:624 yen per month; Asahi:633 yen per month; Mainichi:664 yen per month, and for the regional and local papers:536 yen per month. The overall average, Nikkei aside, is 591 yen per month. Must I state 
the obvious, that the content of the higher-priced papers may be more esteemed than that of the others? If nevertheless we accept these estimates as measuring a collusive pricing effect, how great is the implied economic waste? The combined morning circulation in 2007 of all these, again Nikkei aside, is 33.4 million.

A back-of-envelope calculation using my estimates of the price elasticities $\xi_{\mathrm{s}}=2.3$ and $\xi_{\mathrm{a}}=3.5$ gives an approximate amount for the economic waste arising from 500 yen per month collusive increase in price of subscription. The calculations are straightforward. I find that the loss in consumer surplus to subscribers is 223-billion yen per year, the loss in consumer surplus to advertisers is about 89-billion yen per year, and the increased profit of the newspaper companies is 16-billion yen per year. Hence, the net waste is roughly 300-billion yen /yr (\$3-billion/yr.). I have placed the precise figures in the text box below.

Summary of effects of collusive pricing on consumer surplus from subscriptions and from advertising and on newspaper profits:

$$
\begin{aligned}
& \Delta \mathrm{CS}_{\mathrm{s}}=1,573-1,796=-223-\text { billion yen } / \mathrm{yr} \\
& \Delta \mathrm{CS}_{\mathrm{a}}=283-372=-89 \text {-billion yen } / \mathrm{yr} .
\end{aligned}
$$

$$
\begin{aligned}
& \Delta \mathrm{CS}=-312 \text {-billion yen } / \mathrm{yr} . \\
& \Delta \Pi=16-\text { billion yen } / \mathrm{yr} . \\
& \Delta \mathrm{CS}+\Delta \Pi=-296 \text {-billion } \mathrm{yen} / \mathrm{yr} .
\end{aligned}
$$

This calculation is crude and ignores some secondary effects such as improvement in newspaper content and substitution toward non-colluding newspapers. Some detailed notes on these welfare calculations may be found in Appendix 2. Here I will sketch the main assumptions used.

The price-cost margin equations:

$$
\begin{aligned}
& \left(\mathrm{p}_{\mathrm{a}}-\mathrm{c}_{\mathrm{a}}\right) / \mathrm{p}_{\mathrm{a}}=1 / \xi_{\mathrm{a}} \\
& \left(\mathrm{p}_{\mathrm{s}}-\mathrm{c}_{\mathrm{s}}\right) / \mathrm{p}_{\mathrm{s}}=1 / \xi_{\mathrm{s}}-\mathrm{p}_{\mathrm{a}} \mathrm{a} / \mathrm{p}_{\mathrm{s}} \mathrm{s},
\end{aligned}
$$

imply that total profit equals

$$
\begin{aligned}
\left(\mathrm{p}_{\mathrm{s}}-\mathrm{c}_{\mathrm{s}}\right) \mathrm{s}+\left(\mathrm{p}_{\mathrm{a}}-\mathrm{c}_{\mathrm{a}}\right) \mathrm{a}+\overline{\mathrm{c}} \mathrm{as}-\mathrm{f}_{\mathrm{k}} \mathrm{k} & =\mathrm{p}_{\mathrm{s}} \mathrm{s} / \xi_{\mathrm{s}}-\mathrm{p}_{\mathrm{a}} \mathrm{a}+\mathrm{p}_{\mathrm{a}} \mathrm{a} / \xi_{\mathrm{a}}+\overline{c a s}-\mathrm{f}_{\mathrm{k}} \mathrm{k} . \\
& =\mathrm{p}_{\mathrm{s}} \mathrm{s} / \xi_{\mathrm{s}}-\mathrm{f}_{\mathrm{a}} \mathrm{a}-\mathrm{f}_{\mathrm{k}} \mathrm{k} .
\end{aligned}
$$


It might seem from this that advertising contributes nothing to profit, but actually it does. Note that revenue from subscriptions $\mathrm{p}_{\mathrm{s}} \mathrm{s}$ in this expression presumes profit-maximizing pricing of subscriptions and advertising. Any increase in the marginal revenue from advertising or reduction in the costs of supplying advertising, lead the newspaper to set a lower price of subscriptions which results in enlarged revenue from subscriptions, and increases the first term in the above expression for total profit.

The welfare calculations assume that collusive subscription pricing has no effect on price of ads per subscriber $\Delta\left(\mathrm{p}_{\mathrm{a}} / \mathrm{s}\right)=0$, which implies also no effect on quantity of ads placed $(\Delta \mathrm{a}=0)$. This amounts to treating any increase in first-copy cost per subscriber caused by decreased circulation as negligible $\Delta\left(f_{a} / s\right)=0$; recall that profit-maximizing implies $p_{a} / s=\left(f_{a} / s+\bar{c}\right)\left(1-1 / \xi_{a}\right)^{-1}$. Increasing the monthly subscription price by 500 yen (raising it to 3,925 yen per month), constricts circulation in the newspapers that join in this, and so also lowers the demand for ads. This reduces the consumer surplus from ads and reduces the newspapers' revenues from advertising. But of course the newspapers enjoy a higher marginal profit (actually reduced marginal losses) in their sales of subscriptions.

The reason why colluding newspapers would profit from all setting the same high subscription price is that the cross-elasticities of demand among them are positive; the rival papers are substitutes in demand. As they adjust their prices together they face a less elastic demand response than would any one of them if it adjusted only its own price. A simple calculation shows that if the 500 yen per month price increase maximizes the profits of the colluding newspapers, then they must face an elasticity of demand with respect to adjustment in their common price of 2.0, compared to the 2.3 estimated elasticity of demand with respect to own price. That is, the average cross-elasticity of demand between each of the sixteen colluding papers seems to be about $0.02(=(2.3-2.0) /(16-1))$. The basis for this calculation is the following: From the expression for price of subscriptions: $p_{s}=\left(c_{0}+\bar{c} k+\overline{c a}-p_{a} a / s\right)\left(1-1 / \xi_{s}\right)^{-1}$, the ratio of non-collusive price to collusive price is:

$$
\mathrm{p}_{\mathrm{s}} / \mathrm{p}_{\mathrm{s}^{*}}=3,425 / 3,925=\left(1-1 / \xi_{\mathrm{s}^{*}}\right) /\left(1-1 / \xi_{\mathrm{s}}\right)=\left(1-1 / \xi_{\mathrm{s}^{*}}\right) /(1-1 / 2.3),
$$

from which it follows that

$$
\left(1-1 / \xi_{\mathrm{s}^{*}}\right)=(0.87)(1-0.43)=0.50=(1-1 / 2.0) .
$$

The cross-elasticities of demand among the colluding papers are thus rather small $(\approx 0.02)$. Otherwise the collusive price increase would be much greater than it is. Based on this, each 
newspaper in Japan seems to have its own base of loyal subscribers, reluctant to switch patronage. Horizontal differentiation is prominent.

A final detail worth addressing is why some local newspapers join in setting the collusive price while many others do not. A related question is what deters defection from the cartel? I should first frankly admit that I do not have good answers. But here goes anyway. On the question of which papers join in setting the collusive price, there seem to be two factors. One is the size of circulation. The colluding local papers are mostly the ones with the largest circulation. The two notable exceptions to this are the Shizuoka Shimbun $\left(s=717,229\right.$, and $p_{s}=2,900$ yen per month) and Tokyo Shimbun ( $\mathrm{s}=585,508$, and $\mathrm{p}_{\mathrm{s}}=3,250$ yen per month). The Tokyo Shimbun is in fact owned by Chunichi which does join in setting the collusive price for its flagship paper based in Nagoya $(s=2,774,585)$. My conjecture is that the local newspapers based in more populous cities face greater cross elasticities of demand with the national dailies (because their readers are sophisticated urbanites interested in the goings on in the cultural center). Participation by the large circulation local papers in the collusive pricing is thus valuable to the other colluders. The smaller circulation newspapers face essentially independent demand and remain outside the collusive ring without consequence. But cross-elasticity of demand can also be too great to sustain inclusion in the cartel, especially if side-payments are problematic. My conjecture is that the Shizuoka Shimbun and Tokyo Shimbun can remain outside the collusive ring because their geographic proximity to the home base of the national papers would make it impossible for them to match the collusive price and remain solvent (Shizuoka lies between Tokyo, the home base of Yomiuri, Asahi and Mainichi, and Nagoya, the home base of Chunichi).

On what deters defection from the cartel by any of the national papers themselves, say, or by the others, the calculation must be that defection would end the cartel. Or there may be some enforcement mechanism that is opaque to me, such as full participation in press club activities being contingent on compliance. The resale price maintenance system assures that deviations from collusive pricing will be detected.

\section{Conclusion.}

Japan's newspaper industry, like those of other nations, is likely soon to be overtaken by the profound technological changes moving all writing from print to electronic media. Economists have a brief time yet to study the peculiar practices of the Japanese newspaper tribe before it all 
disappears or at least evolves. When the obituary for Japanese daily print newspapers is finally written, a few lines in it should be devoted to resale price maintenance. Japan's leading national newspapers and a dozen of the largest regional and local papers, protected by a special 1953 exemption from antimonopoly law, have persistently kept their monthly subscription prices at the same common level, about 15 percent higher than they would otherwise have set. In doing so they added 16-billion yen per year to their own profit, based on my estimates here, but imposed a $¥ 300$-billion per year burden on the nation. 
Appendix 1. Data sources:

pages of ads, total pages:

Dentsu Inc. (Annual a). Dentsuu koukoku nenkan (Dentsu advertising annual), Dentsu.

subscription prices, circulation:

Dentsu Inc. (Annual b). Dentsuu shinbun nenkan (Dentsu newspaper annual), Dentsu.

prices of advertising:

Koukoutantou.com. Website. http://www.koukokutantou.com/newspaper 1.html 
Appendix 2. Some notes on the welfare calculation.

Here let asterisk * denote observations under the collusive pricing regime, and let no asterisk denote the counterfactual absence of collusion.

(i). Givens:

Revenue from ads relative to revenue from subscriptions for newspapers with $\mathrm{s}>800,000$ (source=Japan Newspaper Association):

$$
\mathrm{p}_{\mathrm{a}} \mathrm{a}^{*} / \mathrm{p}_{\mathrm{s}} \mathrm{s}^{*}=0.45
$$

Morning circulation 2007 for dailies with subscription price 3,925 yen/mo: $\mathrm{s}^{*}=33.4$-million.

(ii). From estimates:

Price elasticity of demand for ads:

$$
\xi_{\mathrm{a}}=3.5
$$

Own-price elasticity of demand for subscriptions in each newspaper:

$$
\xi_{\mathrm{s}}=2.3
$$

Collusive increase in monthly subscription price:

$$
\mathrm{p}_{\mathrm{s}}=3,425 \mathrm{yen} / \mathrm{mo} . \rightarrow \mathrm{p}_{\mathrm{s}^{*}}=3,925 \mathrm{yen} / \mathrm{mo} \text {. }
$$

(iii). Inferences (assuming $\Delta\left(\mathrm{p}_{\mathrm{a}} / \mathrm{s}\right)=0$, and so $\Delta \mathrm{a}=0$; and assuming $\left.\Delta \mathrm{k}=0\right)$ :

Implied price elasticity of demand for subscriptions as prices of colluding newspapers are adjusted together:

$$
\xi_{\mathrm{s}^{*}}=1.97
$$

...reasoning:

From expression for price of subscriptions: $\mathrm{p}_{\mathrm{s}}=\left(\mathrm{c}_{0}+\overline{\mathrm{c}} \mathrm{k}+\overline{\mathrm{c}} \mathrm{a}-\mathrm{p}_{\mathrm{a}} \mathrm{a} / \mathrm{s}\right)\left(1-1 / \xi_{\mathrm{s}}\right)^{-1}$, $\mathrm{p}_{\mathrm{s}} / \mathrm{p}_{\mathrm{s}^{*}}=3,425 / 3,925=\left(1-1 / \xi_{\mathrm{s}^{*}}\right) /\left(1-1 / \xi_{\mathrm{s}}\right)=\left(1-1 / \xi_{\mathrm{s}^{*}}\right) /(1-1 / 2.3)$.

$\left(1-1 / \xi_{s^{*}}\right)=(0.87)(1-0.43)=(1-1 / 1.97)$

Implied decrease in circulation caused by collusive increase in subscription price:

$\mathrm{s}=43.7$-million $\rightarrow \mathrm{s} *=33.4$-million

...reasoning:

From demand for subscriptions: $\mathrm{s}=\mathrm{A} \mathrm{p}_{\mathrm{s}^{*}}{ }^{-\xi^{*}} \mathrm{k}^{\theta}$

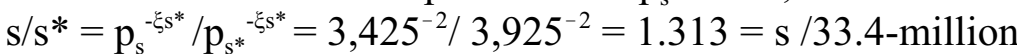

Implied decrease in 2007 annual revenue from subscriptions caused by collusive increase in monthly subscription price:

$$
\mathrm{p}_{\mathrm{s}} \mathrm{s}=1,796-\text { billion yen/yr } \rightarrow \mathrm{p}_{\mathrm{s}^{*}} \mathrm{~s}^{*}=1,573 \text {-billion } \mathrm{yen} / \mathrm{yr} \text {. }
$$


Implied decrease in advertising revenue caused by the decrease in circulation that was induced by collusive increase in price of subscriptions:

$\mathrm{p}_{\mathrm{a}} \mathrm{a}=930$-billion yen/ yr. $\rightarrow \mathrm{p}_{\mathrm{a}^{*}} \mathrm{a}^{*}=708$-billion $\mathrm{yen} / \mathrm{yr}$.

...reasoning:

From assuming $\Delta\left(\mathrm{p}_{\mathrm{a}} / \mathrm{s}\right)=0$, and so $\Delta \mathrm{a}=0$; and assuming $\Delta \mathrm{k}=0$, and given $\mathrm{p}_{\mathrm{a}^{*}} \mathrm{a}^{*} / \mathrm{p}_{\mathrm{s}^{*}} \mathrm{~s}^{*}=0.45$, deduce that $\mathrm{p}_{\mathrm{a}^{*}} \mathrm{a}^{*}=0.45(1,573)=708$ billion yen $/ \mathrm{yr}$. ;

and $\mathrm{p}_{\mathrm{a}} \mathrm{a} / \mathrm{s}=0.45 \mathrm{p}_{\mathrm{s}^{*}}$, so $\mathrm{p}_{\mathrm{a}} \mathrm{a}=0.45 \mathrm{p}_{\mathrm{s}^{*}} \mathrm{~s}^{*}\left(\mathrm{~s} / \mathrm{s}^{*}\right)=708(1.313)=930$-billion yen $/ \mathrm{yr}$.

The consumer surplus of subscribers:

$=\mathrm{p}_{\mathrm{s}^{*} \mathrm{~s}} /\left(\xi_{\mathrm{s}^{*}}-1\right)=\mathrm{p}_{\mathrm{s}^{*} \mathrm{~s}} /(2.0-1)=\mathrm{p}_{\mathrm{s}^{*} \mathrm{~s}}$

$\mathrm{CS}_{\mathrm{s}}=1,796$ billion yen/yr $\rightarrow 1,573$-billion yen/ yr.

The consumer surplus of advertisers:

$=\mathrm{p}_{\mathrm{a}} \mathrm{a} /\left(\xi_{\mathrm{a}}-1\right)=\mathrm{p}_{\mathrm{a}} \mathrm{a} /(3.5-1)=0.4 \mathrm{p}_{\mathrm{a}} \mathrm{a}$

$\mathrm{CS}_{\mathrm{a}}=372-$ billion yen/yr $\rightarrow$ 283-billion yen/ $\mathrm{yr}$.

Change in profit resulting from collusion :

$=\left(\mathrm{p}_{\mathrm{s}^{*}} \mathrm{~s}^{*} / \xi_{\mathrm{s}^{*}}-\mathrm{f}_{\mathrm{a}} \mathrm{a}-\mathrm{f}_{\mathrm{k}} \mathrm{k}\right)-\left(\mathrm{p}_{\mathrm{s}} \mathrm{s} / \xi_{\mathrm{s}}-\mathrm{f}_{\mathrm{a}} \mathrm{a}-\mathrm{f}_{\mathrm{k}} \mathrm{k}\right)$

$=\mathrm{p}_{\mathrm{s} *} \mathrm{~s} * / \xi_{\mathrm{s} *}-\mathrm{p}_{\mathrm{s}} \mathrm{s} / \xi_{\mathrm{s}}$

$\Delta \Pi=1,573 / 1.97-1,796 / 2.3=797-781=16$-billion yen $/ \mathrm{yr}$.

Summary:

$\mathrm{CS}_{\mathrm{s}}=1,796$ billion yen/yr $\rightarrow 1,573$-billion yen/ yr.

$\mathrm{CS}_{\mathrm{a}}=$ 372-billion yen/yr $\rightarrow$ 283-billion yen/ yr.

$\Delta \mathrm{CS}_{\mathrm{s}}=1,573-1,796=-223$-billion yen $/ \mathrm{yr}$

$\Delta \mathrm{CS}_{\mathrm{a}}=283-372=-89$-billion yen $/ \mathrm{yr}$.

$\Delta \mathrm{CS}=-312$-billion yen $/ \mathrm{yr}$.

$\Delta \Pi=$ 16-billion yen $/ \mathrm{yr}$.

$\Delta \mathrm{CS}+\Delta \Pi=-296$-billion yen $/ \mathrm{yr}$. 


\section{References}

Argentesi, Elena and Lapo Filistrucchi. (2007). "Estimating Market Power in a Two-Sided Market: The Case of Newspapers", Journal of Applied Econometrics, vol. 22, pp. 12471266.

Armstrong, Mark. (2006). "Competition in Two-Sided Markets", The RAND Journal of Economics, vol. 37, No. 3 (Autumn), pp. 668-691.

Blair, Roger D. and Richard E. Romano. (1993). "Pricing Decisions of the Newspaper Monopolist", Southern Economic Journal, vol. 59, no. 4 (April), pp. 721-732.

Chandra, Ambarish and Allan Collard-Wexler. (2008). "Mergers in Two-Sided Markets: An Application to the Canadian Newspaper Industry", Journal of Economics and Management Strategy, forthcoming.

Dentsu Inc. (Annual a). Dentsuu koukoku nenkan (Dentsu advertising annual), Dentsu.

Dentsu Inc. (Annual b). Dentsuu shinbun nenkan (Dentsu newspaper annual), Dentsu.

Dentsu Inc. (2009). Jouhou medeia hakushou 2009 (Information media white paper 2009), Daiyamondo sha.

Facta (2007). Chou-Mai-Yomi-Kei VS chihoushi no shea arasoi, dokusen nyuushu, tadoufuken ichiran (Asahi Mainchi Yomiuri Nikkei vs regional newspapers, rivalry for shares and monopolization, summary of number of copies issued in each prefecture), Facta, July 2007. http://facta.co.jp/article/200707008.html

Flath, David. (1989). "Vertical Restraints in Japan," Japan and the World Economy, 1: 187-203.

Japan Fair Trade Commission. Chosakubutsu saihan kyougikai (dai hakkai kaigou) gijiroku nado kouhyou ni tsuite (Official announcements of the eighth meeting of the conference on resale pricing of printed items). Shinbun ryuutsuu-torihiki kankou genjou (Current state of transaction practices in newspaper distribution), shiryou ni (Data tranche no. 2) http://www.jftc.go.jp/pressrelease/08.july/080724tenpu02.pdf

Japan Fair Trade Commission, "Specific Unfair Trade Practices in the Newspaper Business", Fair Trade Commission Notification No. 9, July 21, 1999.

Japan Newspaper Publishers and Editors Association. Deetabukku nihon no shinbun (Databook on Japanese newspapers), nihon shinbun kyokai, annual.

Jullien, Bruno and Patrick Rey. (2007). "Resale Price Maintenance and Collusion", The Rand Journal of Economics, vo. 38, no. 4 (Winter), pp. 983-1001.

Koukoutantou.com. Website. http://www.koukokutantou.com/newspaper 1.html 
Nikae, Daisuke. (2010). "Uniform Pricing in the Japanese Newspaper Industry”, unpublished manuscript.

Picard, Robert G. (1998). "A Note on the Relations Between Circulation Size and Newspaper Advertising Rates", The Journal of Media Economics, vol. 11, no. 2, pp. 47-55.

Rosse, James N. (1970). "Estimating Cost Function Parameters Without Using Cost Data: Illustrated Methodology", Econometrica, vol. 38, no. 2 (March), pp. 256-275.

Telser, Lester. (1960). "Why Should Manufactureres Want Fair Trade?", The Journal of Law and Economics, vol.3, pp. 86-105.

Van Cayseele, Patrick and Stijn Vanormelingen. (2009). "Prices and Network Effects in TwoSided Markets: the Belgian Newspaper Industry", unpublished manuscript. 
Table 1. Regression estimates relating newspaper ad pricing to circulation.

\begin{tabular}{|c|c|c|c|c|}
\hline & Advertising & \multicolumn{3}{|c|}{ Advertising rate for display ad } \\
\hline & $1 \mathrm{~cm} \times 1$ dan & 1 dan & 5 dan & 15 dan \\
\hline Intercept & $\begin{array}{r}11,309 \\
11.2\end{array}$ & $\begin{array}{r}112,692 \\
8.6\end{array}$ & $\begin{array}{r}100,875 \\
8.2\end{array}$ & $\begin{array}{r}93,420 \\
6.4\end{array}$ \\
\hline Circulation (2003) & $\begin{array}{r}0.019 \\
19.1\end{array}$ & $\begin{array}{r}0.440 \\
34.0\end{array}$ & $\begin{array}{r}0.416 \\
34.2\end{array}$ & $\begin{array}{r}0.352 \\
24.3\end{array}$ \\
\hline R-Square & 0.756 & 0.908 & 0.909 & 0.835 \\
\hline$n=119$ & & & & \\
\hline
\end{tabular}

Note. The numbers below the parameter estimates are t-statistics. The sample includes observations for each edition of each newspaper: morning and evening editions, national and local papers. 
Table 2. Descriptive statistics on Japanese newspapers, 2007.

The 37 newspapers in the sample with subscription prices less than 3,925 yen per month

Variable
Subscription price $(¥ /$ mo.)
Circulation
Content pages per month
Pages per month
Ad Pages per month
Ad pages per month
divided by circulation

\section{Mean Std Dev Minimum Maximum}

The 28 morning editions of the 16 newspapers in the sample with subscription prices of 3,925 yen per month

\begin{tabular}{rrrr}
\hline Mean & Std Dev & Minimum & Maximum \\
& & & \\
3,925 & 0 & 3,925 & 3,925 \\
$1,153,830$ & $1,374,653$ & 72,617 & $6,068,547$ \\
599 & 46 & 498 & 743 \\
1,034 & 123 & 791 & 1,230 \\
435 & 103 & 267 & 640 \\
& & & \\
0.00100 & 0.00109 & 0.00011 & 0.00448
\end{tabular}


Table 3. Explaining the newspaper subscription prices that are less than 3,925 yen per month

\begin{tabular}{|c|c|c|c|}
\hline Explanatory Variable & & $\begin{array}{l}\text { Subscription } \\
\text { Price } \\
\text { (¥/month) } \\
\end{array}$ & t-value \\
\hline Intercept & & 2,723 & \\
\hline $\begin{array}{l}\text { Dummy equal to one if } \\
\text { price includes both } \\
\text { morning and evening } \\
\text { editions }\end{array}$ & & 434 & \\
\hline Pages per month & $\mathrm{k}+\mathrm{a}$ & 0.5 & 0.88 \\
\hline $\begin{array}{l}\text { Pages of advertising } \\
\text { per month }\end{array}$ & $\mathrm{a}$ & -0.7 & -0.60 \\
\hline $\begin{array}{l}\text { Pages of advertising } \\
\text { divided by circulation }\end{array}$ & $\mathrm{a} / \mathrm{s}$ & $-103,929$ & -1.65 \\
\hline
\end{tabular}

R-squared $=0.436$

$\mathrm{n}=37$ 
Table 4. Out-of-sample prediction errors for monthly subscription price.

\begin{tabular}{|c|c|c|c|c|c|c|}
\hline \multirow{3}{*}{ Newspaper } & \multicolumn{2}{|c|}{ Circulation } & \multicolumn{4}{|c|}{ Subscription price } \\
\hline & & & \multirow{2}{*}{$(¥ / \mathrm{mo})}$. & \multirow{2}{*}{$\begin{array}{l}\text { Predic- } \\
\text { tion } \\
\end{array}$} & \multirow[t]{2}{*}{ s.d. } & \multirow[t]{2}{*}{ Error } \\
\hline & morning & evening & & & & \\
\hline \multirow{2}{*}{$\begin{array}{l}\text { THE YOMIURI SHIMBUN } \\
\text { (Tokyo) }\end{array}$} & $6,068,547$ & & \multirow[b]{2}{*}{3,925} & \multirow[b]{2}{*}{3,361} & \multirow[b]{2}{*}{390} & \multirow[b]{2}{*}{564} \\
\hline & & $2,357,250$ & & & & \\
\hline \multirow{2}{*}{$\begin{array}{l}\text { YOMIURI SHIMBUN } \\
\text { (Hokkaido) }\end{array}$} & 232,992 & & \multirow{2}{*}{3,925} & \multirow{2}{*}{3,168} & \multirow{2}{*}{339} & \multirow{2}{*}{757} \\
\hline & & 64,396 & & & & \\
\hline \multirow{2}{*}{$\begin{array}{l}\text { YOMIURI SHIMBUN } \\
\text { (Osaka) }\end{array}$} & $2,547,583$ & & \multirow{2}{*}{3,925} & \multirow{2}{*}{3,361} & \multirow{2}{*}{372} & \multirow{2}{*}{564} \\
\hline & & $1,332,683$ & & & & \\
\hline $\begin{array}{l}\text { YOMIURI SHIMBUN } \\
\text { (Nagoya) morning }\end{array}$ & 160,333 & & 3,007 & 2,713 & 331 & 294 \\
\hline \multirow{2}{*}{$\begin{array}{l}\text { YOMIURI SHIMBUN } \\
\text { (Seibu) }\end{array}$} & 914,687 & & \multirow{2}{*}{3,925} & \multirow{2}{*}{3,324} & \multirow{2}{*}{338} & \multirow{2}{*}{601} \\
\hline & & 109,479 & & & & \\
\hline YOMIURI SHIMBUN & 108,299 & & & & & \\
\hline (Hokuriku) & & 5,180 & 3,925 & 2,959 & $3 / 9$ & 966 \\
\hline YOMIURI SHIMBUN & $10,032,441$ & $3,868,988$ & & & & \\
\hline THE ASAHI SHIMBUN & $4,358,660$ & & & & & \\
\hline (Tokyo) & & $1,958,061$ & 3,925 & 3,369 & 378 & 556 \\
\hline THE ASAHI SHIMBUN & 155,750 & & 3025 & 3102 & 335 & 823 \\
\hline (Hokkaido) & & 53,740 & 3,925 & 3,102 & 335 & 823 \\
\hline THE ASAHI SHIMBUN & $2,336,911$ & & & 3366 & 348 & 559 \\
\hline (Osaka) & & $1,294,724$ & 3,925 & 3,566 & 348 & 509 \\
\hline THE ASAHI SHIMBUN & 424,246 & & & & 313 & \\
\hline (Nagoya) & & 146,107 & 3,925 & 3,293 & 313 & 632 \\
\hline THE ASAHI SHIMBUN & 791,140 & & & & & \\
\hline (Seibu) & & 135,628 & 3,925 & 3,332 & 331 & 593 \\
\hline THE ASAHI SHIMBUN & $8,066,707$ & $3,588,260$ & & & & \\
\hline & $1,809,446$ & & & & & \\
\hline THE NIKKEI (Tokyo) & & 937,844 & 4,383 & 3,382 & 391 & 1,001 \\
\hline $\begin{array}{l}\text { THE NIKKEI (Hokkaido) } \\
\text { morning }\end{array}$ & 56,533 & & 3,568 & 1,875 & 697 & 1,693 \\
\hline THF NIKKFI (Osaka) & 775,434 & & 4383 & 3333 & 384 & 1050 \\
\hline IHE NIKKEI (Usaka) & & 476,176 & 4,583 & 3,353 & 384 & 1,050 \\
\hline & 204,996 & & 4383 & 3083 & 403 & 1300 \\
\hline THE NIKKEI (Nagoya) & & 143,319 & 4,583 & & & \\
\hline THF NIKKEI (Seihu) & 194,100 & & 4383 & 3073 & 101 & 1210 \\
\hline IHE NIKKEI (SeIDU) & & 66,363 & 4,583 & $3,0 / 3$ & 401 & 1,310 \\
\hline THE NIKKEI & $3,040,509$ & $1,623,702$ & & & & \\
\hline & $2,774,585$ & & & & & \\
\hline THE CHUNICHI SHIMBUN & & 650,297 & 3,925 & 3,394 & 323 & 531 \\
\hline
\end{tabular}




\begin{tabular}{|c|c|c|c|c|c|c|}
\hline \multirow{3}{*}{ Newspaper } & \multicolumn{2}{|c|}{ Circulation } & \multicolumn{4}{|c|}{ Subscription price } \\
\hline & & & \multirow[t]{2}{*}{$(¥ / \mathrm{mo})}$. & \multirow{2}{*}{$\begin{array}{l}\text { Predic- } \\
\text { tion } \\
\end{array}$} & \multirow[t]{2}{*}{ s.d. } & \multirow[t]{2}{*}{ Error } \\
\hline & morning & evening & & & & \\
\hline \multirow{2}{*}{$\begin{array}{l}\text { MAINICHI SHIMBUN } \\
\text { (Tokyo) }\end{array}$} & 1.640 .998 & & \multirow{2}{*}{3,925} & \multirow{2}{*}{3,378} & \multirow{2}{*}{305} & \multirow{2}{*}{547} \\
\hline & & 462,952 & & & & \\
\hline \multirow{2}{*}{$\begin{array}{l}\text { MAINICHI SHIMBUN } \\
\text { (Hokkaido) }\end{array}$} & 72,617 & & \multirow{2}{*}{3,925} & \multirow{2}{*}{3,009} & \multirow{2}{*}{333} & \multirow{2}{*}{916} \\
\hline & & 17,697 & & & & \\
\hline \multirow{2}{*}{$\begin{array}{l}\text { MAINICHI SHIMBUN } \\
\text { (Nagoya) }\end{array}$} & 176,101 & & \multirow{2}{*}{3,925} & \multirow{2}{*}{3,245} & \multirow{2}{*}{294} & \multirow{2}{*}{680} \\
\hline & & 49,069 & & & & \\
\hline \multirow{2}{*}{$\begin{array}{l}\text { MAINICHI SHIMBUN } \\
\text { (Seibu) }\end{array}$} & 664,559 & & \multirow{2}{*}{3,925} & \multirow{2}{*}{3,312} & 302 & 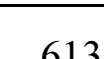 \\
\hline & & 102,896 & & & 302 & 015 \\
\hline MAINICHI SHIMBUN & $1,419,552$ & & 3925 & 3360 & 306 & 565 \\
\hline (Osaka) & & 830,585 & $J, 92 J$ & 5,500 & 500 & $50 J$ \\
\hline MAINICHI SHIMBUN & $3,973,827$ & $1,463,199$ & & & & \\
\hline $\begin{array}{l}\text { SANKEI SHIMBUN } \\
\text { (Tokyo) }\end{array}$ & 975,652 & & 2,950 & 2,962 & 302 & -12 \\
\hline SANKEI SHIMBUN (Osaka) & $1,224,957$ & & 3,925 & 3,386 & 300 & 539 \\
\hline & & 633,154 & $3,9<5$ & 3,500 & 300 & נכנד \\
\hline SANKEI SHIMBUN & $2,200,609$ & 633,154 & & & & \\
\hline & & & & & & \\
\hline HOKKAIDO SHIMRIN & $1,204,151$ & & 3925 & 3341 & 349 & 584 \\
\hline HUNAAIDU STIIVIDON & & 639,634 & J,920 & $J, 341$ & 349 & 304 \\
\hline THE NISHI-NIPPON & 854,655 & & & & & \\
\hline SHIMBUN & & 175,518 & 3,925 & 3,343 & 322 & 582 \\
\hline THE CHUGOKU & 717,794 & & 3025 & & & \\
\hline SHIMBUN & & 73,628 & $3,9<5$ & 3,504 & 308 & 501 \\
\hline KORE SHIMRIN & 561,881 & & 3925 & 3359 & 297 & 566 \\
\hline NUDE SHIIVIDUIV & & 254,782 & J,920 & (כ, & 291 & 500 \\
\hline KYOTO SHIMBUN & 510,000 & & 3925 & 3344 & 297 & 581 \\
\hline & & 317,881 & & & & \\
\hline THE KAHOKU SHIMPO & 501,356 & & 3.925 & 3347 & 299 & 578 \\
\hline & & 109,871 & $3,9<5$ & & & \\
\hline NIIGATA NIPPO & 495,354 & & 3,925 & 3.328 & 305 & 597 \\
\hline DIIUA I A IVIT & & 55,784 & $J, 90 \mathrm{~J}$ & $J, J<0$ & $30 J$ & ו \\
\hline SHINANO MAINICHI & 485,231 & & 3025 & 3356 & 300 & 560 \\
\hline SHIMBUN & & 52,492 & J,920 & ( & 300 & 509 \\
\hline THE SANYO SHIMBUN & 466,627 & & 3.925 & 3.372 & 302 & 553 \\
\hline IHE SAIV TO SHIVID UN & & 72,015 & 3,920 & J,J/2 & 302 & J5 \\
\hline THE HOKKOKU & 343,274 & & 3925 & 3357 & 315 & 568 \\
\hline SHIMBUN & & 84,808 & $J, 920$ & ו וכנכד & & 500 \\
\hline TOKUSHIMA SHIMBUN & 254,724 & & 3.925 & 3.228 & 302 & 697 \\
\hline 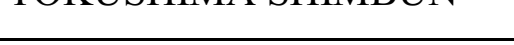 & & & & & & \\
\hline
\end{tabular}


Figure 1. Morning circulation in 2007 of Japan's national, local and regional newspapers in each prefecture, ranging from west (Okinawa) to east (Hokkaido).

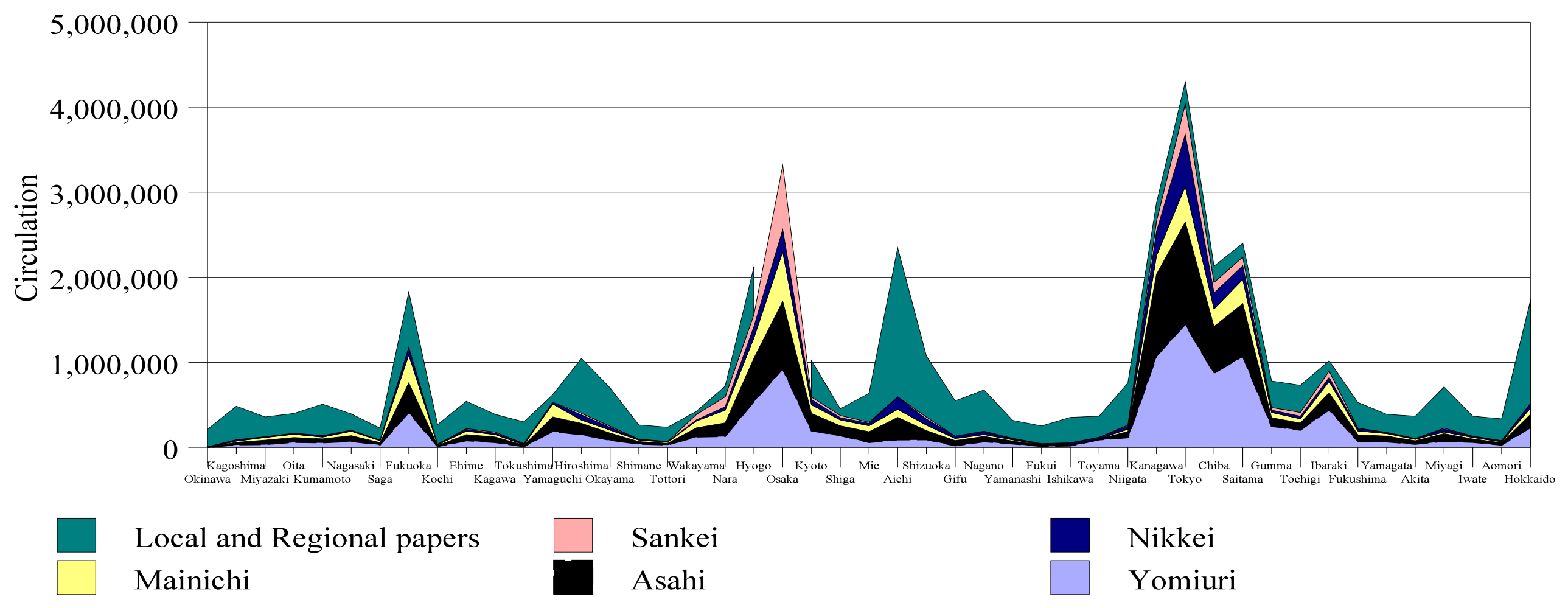

Source: Chou-Mai-Yomi-Kei VS chihoushi no shea arasoi, dokusen nyuushu, tadoufuken ichiran (Asahi Mainchi Yomiuri Nikkei vs regional newspapers, rivalry for shares and monopolization, summary of number of copies issued in each prefecture), Facta, July 2007. http://facta.co.jp/article/200707008.html 